\title{
IN VIVO TOXICITY STUDY OF DIALKYL DISULPHIDES
}

Kucherskoy $\mathrm{SA}^{1,2}$, Alikbaeva LA ${ }^{2}$

${ }^{1}$ Research Institute of Hygiene, Occupational Pathology and Human Ecology of the Federal Medical Biological Agency, St. Petersburg, Russia

${ }^{2}$ North-Western State Medical University named after I.I. Mechnikov, St. Petersburg, Russia

As a result of the industrial purification of hydrocarbons from mercaptans, tens of thousands of tons of dialkyl disulphides and their mixtures, the toxicity and hazard of which has not been fully understood, are accumulated annually. The exposure standards have been developed only for dimethyl disulphide. The study was aimed to define toxicometry parameters for diethyl disulphide, disulphide oil, and the mixture of dialkyl disulphides. Toxicology studies involving male outbred rats made it possible to define the median lethal doses and concentrations: diethyl disulphide - after intragastric injection $\mathrm{DL}_{50}=1575 \mathrm{mg} / \mathrm{kg}$, after the 4 -hour inhalation exposure $\mathrm{CL}_{50}=18,700 \mathrm{mg} / \mathrm{m}^{3}$, after intraperitoneal injection $\mathrm{DL}_{50}=1134 \mathrm{mg} / \mathrm{kg}$, and after skin application $\mathrm{DL}_{50}>2500 \mathrm{mg} / \mathrm{kg}$; mixture of dialkyl disulphides - after intragastric injection DL50 $=428 \mathrm{mg} / \mathrm{kg}$, after the 4-hour inhalation exposure $\mathrm{CL}_{50}=4510 \mathrm{mg} / \mathrm{m}^{3}$, after intraperitoneal injection DL $\mathrm{L}_{50}=212 \mathrm{mg} / \mathrm{kg}$, and after skin application $\mathrm{DL}_{50}>2500 \mathrm{mg} / \mathrm{kg}$; disulphide oil — after intragastric injection $\mathrm{DL}_{50}=448 \mathrm{mg} / \mathrm{kg}$, after the 4-hour inhalation exposure $\mathrm{CL}_{50}=4534 \mathrm{mg} / \mathrm{m}^{3}$, after intraperitoneal injection $\mathrm{DL}_{50}=156 \mathrm{mg} / \mathrm{kg}$, and after skin application $\mathrm{DL}_{50}>2500 \mathrm{mg} / \mathrm{kg}$. The hazard assessment for dialkyl disulphides and their mixtures was performed.

Keywords: dialkyl disulphides, dimethyl disulphide, diethyl disulphide, methylethyl disulphide, disulphide oil, acute toxicity, $\mathrm{LD}_{50}, \mathrm{LC}_{50}, \mathrm{hazard}_{\mathrm{C}} \mathrm{Class}$

Acknowlegements: we would like to thank Shkaeva IE, the leading researcher at the Research Institute of Hygiene, Occupational Pathology and Human Ecology of the FMBA, for study management, and Nikolaev Al, the leading researcher at the Research Institute of Hygiene, Occupational Pathology and Human Ecology of the FMBA, for assistance in mathematical processing of the results.

Author contribution: Kucherskoy SA — conducting toxicology studies; Alikbaeva LA — overal management.

Compliance with ethical standards: the study was approved by the Ethics Committee of the North-Western State Medical University named after I.I. Mechnikov (protocol № 8 dated November 11, 2020); laboratory animals were kept and fed in accordance with SP 2.2.1.3218-14 "Sanitary and Epidemiological Requirements for the Device, Equipment and Maintenance of Experimental Biological Clinics (Vivariums)", as well as with the "Guide for Care and Use of Laboratory Animals» (USA).

$\triangle$ Correspondence should be addressed: Semen A. Kucherskoy

Kapitolovo, str. 93, r. p. Kuzmolovsky, Vsevolozhsky r., Leningradskaya obl., 188663; kucherskoi@gpech.ru

Received: 29.05.2021 Accepted: 15.06.2021 Published online: 25.06.2021

DOI: $10.47183 /$ mes.2021.015

\section{ТОКСИЧНОСТЬ ДИАЛКИЛДИСУЛЬФИДОВ В ЭКСПЕРИМЕНТАХ IN VIVO}

\section{С. А. Кучерской ${ }^{1,2}$, Л. А. Аликбаева²}

${ }^{1}$ Научно-исследовательский институт гигиены, профпатологии и экологии человека Федерального медико-биологического агентства, Санкт-Петербург, Россия ${ }^{2}$ Северо-Западный государственный медицинский университет имени И. И. Мечникова, Санкт-Петербург, Россия

В результате промышленной очистки углеводородного сырья от меркаптанов ежегодно накопливаются десятки тысяч тонн диалкилдисульфидов и их смесей, токсичность и опасность которых в полной мере не изучена. Гигиенические нормативы разработаны только для диметилдисульфида. Целью исследования было установить параметры токсикометрии для диэтилдисульфида, “дисульфидного масла» и смеси диалкилдисульфидов. В токсикологических исследованиях на самцах беспородных крыс установлены среднесмертельные дозы и концентрации: диэтилдисульфида - при внутрижелудочном введении $\mathrm{DL}_{50}=1575$ мг/кг, при ингаляционном 4-часовом воздействии $\mathrm{CL}_{50}=18700$ мг/M³, при внутрибрюшинном введении

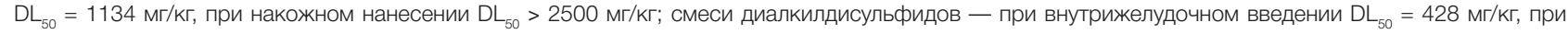

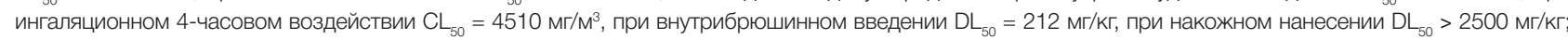
дисульфидного масла - при внутрижелудочном введении $\mathrm{DL}_{50}=448 \mathrm{Mr} / \mathrm{K}$, при ингаляционном 4-часовом воздействии $\mathrm{CL}_{50}=4534 \mathrm{Mr} / \mathrm{M}^{3}$, при внутрибрюшинном введении $\mathrm{DL}_{50}=156$ мг/кг, при накожном нанесении $\mathrm{DL}_{50}>2500$ мг/кг. Проведена оценка опасности диалкилдисульфидов и их смесей.

Ключевые слова: диалкилдисульфид, диметилдисульфид, диэтилдисульфид, метилэтилдисульфид, дисульфидное масло, острая токсичность, LD $\mathrm{LC}_{50}$, класс опасности

Благодарности: И. Е. Шкаевой - ведущему научному сотруднику НИИ ГПЭЧ ФМБА России за руководство при выполнении исследований. А. И. Николаеву - ведущему научному сотруднику НИИ ГПЭЧ ФМБА России за помощь в математической обработке результатов исследования.

Вклад авторов: С. А. Кучерской — проведение токсикологических исследований; Л. А. Аликбаева - общее руководство.

Соблюдение этических стандартов: исследование одобрено этическим комитетом СЗГМУ им. И. И. Мечникова (протокол № 8 от 11 ноября 2020 г.); условия содержания и уход за животными соответствовали нормативам СП 2.2.1.3218-14 «Санитарно-эпидемиологические требования к устройству, оборудованию и содержанию экспериментально-биологических клиник (вивариев)», а также требованиям руководства «Guide for Care and Use of Laboratory Animals» (USA).

$\bigotimes$ Для корреспонденции: Семен Александрович Кучерской

ст. Капитолово, корп. № 93, г. п. Кузьмоловский, Всеволожский район, Ленинградская область, 188663; kucherskoi@gpech.ru

Статья получена: 29.05.2021 Статья принята к печати: 15.06.2021 Опубликована онлайн: 25.06.2021

DOI: $10.47183 /$ mes.2021.015

As a result of the industrial purification of hydrocarbons from mercaptans, tens of thousands of tons of dialkyl disulphides and their mixtures are being accumulated annually [1]. Dialkyl disulphides are used in oil industry as coke formation inhibitors in pyrolysis furnaces, and sulfiding agents, the hydrotreating and hydrocracking catalysts. In agriculture, dialkyl disulphides are used as insecticides, and in food industry, these are used as flavoring agents [2-7]. Despite the widespread industrial application of dialkyl disulphides, the exposure standards for diethyl disulphide, methylethyl disulphide, and disulphide oil have not been established. In order to establish the exposure standards and to evaluate the hazards of the substances, we conducted toxicology studies of the dialkyl disulphide effects in the acute experiment. 


\section{METHODS}

Toxicity of dialkyl disulphides was assessed amidst single and repeated exposure, the study involved male outbred rats with initial weight of 220-250 g, and male mice with the weight of 20-25 g (nursery of laboratory animals "Rappolovo"; Leningrad Region). The delivered batches of animals had veterinary certificates specifying the animals' age and average weight, and indicating the absence of systemic diseases and parasitic infestation. The animals were taken to quarantine unit of the vivarium, where adaptation took place for 14 days. The animals were kept under standard housing conditions; they were given a standard diet, and had free access to water. During the quarantine period, each animal underwent daily examinations (behavior, overall condition, morbidity and mortality were evaluated). At the beginning of the experiments the animals, meeting the inclusion criteria, were randomized to groups. Animals, not meeting the inclusion criteria, were excluded from the study. Air change rate, room temperature and humidity were monitored daily. The temperature was maintained within the range of $20-24{ }^{\circ} \mathrm{C}$, the relative humidity was within the range of $50-70 \%$, the air change rate was 10 air changes per hour, and the lighting conditions were $12 \mathrm{~h}$ of light per day. The animals were euthanized in $\mathrm{CO}_{2}$ chambers.

For the experiment the animals were divided into homogeneous groups based on the body weight (8-10 animals per group); laboratory animals were labeled on an individual basis.

Acute toxicity of dialkyl disulfides was assessed by intragastric injection, intraperitoneal injection, skin application, and inhalation [8].

The studied substances were as follows:

- diethyl disulphide (DEDS) with mass fraction of parent substance at least $99 \%$, and mass fraction of dimethyl disulfide impurities at least 1\%;

- disulphide oil (DSO) with mass fraction of dimethyl disulfide of $75.14 \%$; mass fraction of diethyl disulphide of $2.08 \%$; mass fraction of methylethyl disulphide of $21.69 \%$; mass fraction of higher dialkyl disulphides $\mathrm{C}_{4}-\mathrm{C}_{8} \mathrm{~S}_{2} \mathrm{H}_{10}-\mathrm{H}_{22} \approx 1 \%$.

- mixture of dialkyl disulphides with mass fraction of DMDS of $26.4 \%$; mass fraction of MEDS of $53.0 \%$; mass fraction of DEDS of $20.7 \%$;

Physical and chemical properties of dialkyl disulphides are presented in Table 1 [9].
Intragastric injections of the substances (at a dose of 75-2000 mg/kg) were performed using the atraumatic probe; vegetable oil was used as a solvent.

The inhalation exposure modeling was performed in the chambers with a volume of $600 \mathrm{dm}^{3}$. The experimental animals were exposed to the following concentrations of dialkyl disulphide vapors: diethyl disulphide 10,000-22,000 mg/m³ disulphide oil $4000-5000 \mathrm{mg} / \mathrm{m}^{3}$; mixture of DADS 3800-6000 $\mathrm{mg} / \mathrm{m}^{3}$. The exposure time for a single inhalation exposure was $2 \mathrm{~h}$ in mice, and $4 \mathrm{~h}$ in rats.

The vapor concentrations in the air within the exposure chambers were controlled by gas chromatography with flame ionization detection.

During the acute experiments, the duration of observation after the exposure to the substance was 14 days. The overall condition, behavior, appearance, and response to external stimuli were evaluated in experimental animals. Clinical manifestations of poisoning were registered. In end of observation period necropsy was performed, the macroscopic examination of internal organs.

\section{RESULTS}

Intragastric injection of the mixture containing DADS and DSO resulted in the animals' death of pulmonary edema, mainly during the first day. Intragastric injection of DEDS resulted in the animals' death delayed until day 7 . Clinical manifestations of acute dialkyl disulphide intoxication were similar: hypo- or adynamia of experimental animals, and decreased respiration rate. Macroscopic examination of the dead animals' internal organs revealed the following: brown lung induration and pulmonary hemorrhage, tracheal froth, dark brown spleen and kidneys, fine liver surface nodularity.

The overall appearance of animals, which survived acute intoxication, was the same as of controls throughout the observation period.

Based on the acute toxicity parameters defined for intragastric injection, the studied dialkyl disulphides are moderately hazardous substances (hazard class 3 [10]). DEDS is assigned hazard class 4 , and the mixture of DADS and disulphide oil is assigned hazard class 3 [11] (Table 2).

The studied substances are supported as mildly hazardous by the species ratio values:

DEDS species ratio: $1575 / 1565=1.006$

Table 1. Physical and chemical properties of dialkyl disulphide samples

\begin{tabular}{|c|c|c|c|}
\hline \multirow{2}{*}{ Indicator } & \multicolumn{3}{|c|}{ Dialkyl disulphides } \\
\hline & DMDS & MEDS & DEDS \\
\hline Chemical formula & $\mathrm{CH}_{3} \mathrm{SSCH}_{3}$ & $\mathrm{CH}_{3} \mathrm{SSC}_{2} \mathrm{H}_{5}$ & $\mathrm{C}_{2} \mathrm{H}_{5} \mathrm{SSC}_{2} \mathrm{H}_{5}$ \\
\hline № CAS & $624-92-0$ & $20333-39-5$ & $110-81-6$ \\
\hline Physical appearance & pale yellow transparent liquid & oleaginous fluid & oleaginous fluid \\
\hline Molecular mass, $\mathrm{g} / \mathrm{mol}$ & 94.2 & 108.23 & 122.25 \\
\hline Density, $\mathrm{g} / \mathrm{cm}^{3}$ & 1.057 & 1.022 & 0.993 \\
\hline Boiling point, ${ }^{\circ} \mathrm{C}$ & 109.7 & 131.6 & 154.1 \\
\hline Refractive index & 1.5259 & 1.5146 & 1.506 \\
\hline Sulphur content, wt $\%$ & 68.09 & 59.26 & 52.46 \\
\hline \multicolumn{4}{|c|}{ Solubility } \\
\hline Water & insoluble & insoluble & sparingly soluble \\
\hline Diethyl ether & soluble & soluble & mixing \\
\hline Ethanol & soluble & soluble & mixing \\
\hline
\end{tabular}

Note: DMDS — dimethyl disulphide; MEDS — methylethyl disulphide; DEDS — diethyl disulphide. 
Table 2. Dialkyl disulphide acute toxicity parameters with intragastric injection

\begin{tabular}{|c|c|c|c|}
\hline \multirow{3}{*}{ Animal species } & \multicolumn{3}{|c|}{ Lethal doses, $\mathrm{mg} / \mathrm{kg}$} \\
\hline & $\mathrm{LD}_{16}$ & $\mathrm{LD}_{50}$ & $\mathrm{LD}_{84}$ \\
\hline & \multicolumn{3}{|c|}{ Diethyl disulphide } \\
\hline Male mice & 942 & $1565 \pm 370$ & 2601 \\
\hline Male rats & 1384 & $1575 \pm 91$ & 1793 \\
\hline \multicolumn{4}{|c|}{ Mixture of DADS } \\
\hline Male mice & 244 & $435 \pm 118$ & 775 \\
\hline Male rats & 307 & $428 \pm 83$ & 597 \\
\hline \multicolumn{4}{|c|}{ Disulphide oil } \\
\hline Male mice & 276 & $381 \pm 56$ & 527 \\
\hline Male rats & 265 & $448 \pm 142$ & 759 \\
\hline
\end{tabular}

Mixture of DADS species ratio: $428 / 435=0.98$.

DSO species ratio: $448 / 381=1.17$.

Upon intraperitoneal injection in rats the acute toxicity parameters has been defined (Table 3), supporting these compounds as being moderately hazardous.

After intraperitoneal injection of the mixture containing DADS and DSO, adynamia occurred within 5 minutes, and the respiration rate decreased in experimental animals. The animals died of respiratory arrest 30-60 min after administration of the substance.

After intraperitoneal injection of DEDS, the experimental animals exhibited psychomotor retardation during one hour, they did not respond to external stimuli. After $4-5 \mathrm{~h}$ the overall appearance of experimental animals was the same as of controls. The animals died of pulmonary edema during the first day after administration of DEDS.

Masroscopic features of internal organs were the same as in case of intragastric injection.

Based on the acute toxicity parameters defined for inhalation exposure, the mixture of DADS and disulphide oil are assigned hazard class 2 [10] and 3 [11]. Based on the $\mathrm{CL}_{50}$ value, DEDS is assigned hazard class 3 [10] and 4 [11] (Table 4).

No significant species differences were defined for dialkyl disulphide inhalation poisoning.

The index of potential inhalation toxicity (IPITac) indicated low hazard upon single inhalation exposure to DEDS (IPITac = $24999.3 / 18,700=1.33$ ), and moderate hazard upon exposure to the mixture of DADS (IPITac $=74004.5 / 4534=16.3)$, and disulphide oil (IPITac $=105336.5 / 4510=23.3)$.

Clinical manidestations of acute inhalation poisoning with dialkyl disulphide vapors were as follows: hypo- or adynamia of experimental animals, signs of hypoxia (moderate cyanosis of faces and paws), and breathing problems. The periods of decreased motor activity were followed by periods of increased motor activity. The animals died of pulmonary edema due to exposure to the mixture of DADS and DSO within $24 \mathrm{~h}$ of inhalation exposure; when exposed to DEDS, the animals died mostly on day 3-5 of observation. Masroscopic features of internal organs were the same as in case of intragastric injection.
The overall appearance and behavior of animal survivors being monitored for 14 days after exposure were the same as those of controls.

It was found that the mixture of DADS and DSO was fatal for a part of mice during the 2-hour exposure with the 2/3 of the tail length placed into test tubes filled with substances; however, DEDS was not fatal for experimental mice.

Upon dermal exposure, the following median lethal doses $\left(D L_{50}\right)$ were defined for experimental rats: mixture of DADS 7400 (5690; 9620) mg/kg, DSO - 3400 (2345; 4930) mg/kg. Based on the median lethal doses upon skin application, the studied substances were assigned hazard class 4 [10]. Skin application of DEDS for $4 \mathrm{~h}$ was never fatal for experimental rats. No signs of skin irritation were observed. Clinical manifestations of acute poisoning upon dermal exposure of experimental animals to dialkyl disulfides were the same as in case of intragastric injection.

The study results were indicative of the substances being hazardous in contact with skin.

After application of one drop of the studied substance on the mucous membrane of the rat's eye, the irritant effect in the form of hyperemia was observed. Hyperemia vanished 1-2 days later, and further observation demonstrated that the experimental rats had the same overall appearance and showed the same dynamic changes of body weight as the controls.

\section{DISCUSSION}

The results obtained for acute oral toxicity of disulfide oil are within a factor of three of the literature data $(1590 \mathrm{mg} / \mathrm{kg}$ reported by Morgott et al., and $428 \mathrm{mg} / \mathrm{kg}$ in our studies) [5], which could indicate different composition of disulphide oil, the use of different experimental animal species, or the use of different solvent for intragastric injection. The article by Morgott et al. [5] refers to the unpublished results obtained at the IIT Research Institute. There is no information about this source in the Scopus, and PubMed databases. The inhalation toxicity data also differ: Morgott et al. [5] report it to be greater than $4840 \mathrm{mg} / \mathrm{m}^{3}$; in our studies $\mathrm{CL}_{50}$ of $4534 \mathrm{mg} / \mathrm{m}^{3}$ was

Table 3. Dialkyl disulphide acute toxicity parameters with single intraperitoneal injection in male rats $(n=10)$

\begin{tabular}{|l|c|c|c|}
\hline \multirow{2}{*}{\multicolumn{2}{|c|}{ Substances }} & \multicolumn{3}{|c|}{ Lethal doses, $\mathrm{mg} / \mathrm{kg}$} \\
\cline { 2 - 4 } & $\mathrm{LD}_{16}$ & $\mathrm{LD}_{50}$ & $1575 \pm 91$ \\
\hline Diethyl disulphide & 1384 & $212 \pm 11$ & 1793 \\
\hline Mixture of DADS & 187 & $156 \pm 33$ & 240 \\
\hline Disulphide oil & 98 & 248 \\
\hline
\end{tabular}


Table 4. Dialkyl disulphide acute toxicity parameters with single inhalation exposure

\begin{tabular}{|c|c|c|c|}
\hline \multirow{2}{*}{ Animal species } & \multicolumn{3}{|c|}{ Lethal concentrations, $\mathrm{mg} / \mathrm{m}^{3}$} \\
\hline & $\mathrm{CL}_{16}$ & $\mathrm{CL}_{50}$ & $\mathrm{CL}_{84}$ \\
\hline \multicolumn{4}{|c|}{ Diethyl disulphide } \\
\hline Male mice & 17630 & $18125 \pm 515$ & 19930 \\
\hline Male rats & 17800 & $18700 \pm 556$ & 19730 \\
\hline \multicolumn{4}{|c|}{ Mixture of DADS } \\
\hline Male mice & 3900 & $4200 \pm 190$ & 4750 \\
\hline Male rats & 3300 & $4534 \pm 519$ & 5120 \\
\hline \multicolumn{4}{|c|}{ Disulphide oil } \\
\hline Male mice & 3900 & $4200 \pm 180$ & 4700 \\
\hline Male rats & 4400 & $4510 \pm 60$ & 4600 \\
\hline
\end{tabular}

established. However, the acute toxicity data for disulfide oil are close to data obtained by Morgott et al. for dimethyl disulfide.

\section{CONCLUSION}

As a result of the experimental studies, the acute toxicity parameters were defined for intragastric injection and inhalation exposure: for DEDS, $\mathrm{DL}_{50}$ was $1575 \mathrm{mg} / \mathrm{kg}$, and $\mathrm{CL}_{50}$ was $18,700 \mathrm{mg} / \mathrm{m}^{3}$; for the mixture of DADS, $\mathrm{DL}_{50}$ was $448 \mathrm{mg} / \mathrm{kg}$, and $\mathrm{CL}_{50}=4510 \mathrm{mg} / \mathrm{m}^{3}$; for $\mathrm{DSO}, \mathrm{DL}_{50}$ was $428 \mathrm{mg} / \mathrm{kg}$, and $\mathrm{CL}_{50}=4534 \mathrm{mg} / \mathrm{m}^{3}$. The median lethal dose $\left(\mathrm{DL}_{50}\right)$ for dermal exposure to the mixture of DADS was $7400 \mathrm{mg} / \mathrm{kg}$, and for DSO it was $3400 \mathrm{mg} / \mathrm{kg}$; DEDS was not fatal in contact with skin. The data obtained show that dialkyl disulfides are the moderately hazardous substances upon single intragastric injection, inhalation exposure, and skin application. Comparison of the studied substances with dimethyl disulfide (DMDS) by toxicity has shown that based on the toxicometry parameters, DEDS is about 9 times less toxic upon intragastric injection, and 3 times less toxic upon single inhalation exposure, compared to DMDS. Comparison of the mixture of DADS and DSO with DMDS has revealed similar inhalation toxicity. The mixture of DADS and disulphide oil is 2 times less toxic upon intragastric injection compared to DMDS. Comparison of DSO and DADS mixture toxicity has shown that impurities do not affect the toxicometry parameters. These toxicometry parameters would be used to define the hazard class and to establish the dialkyl disulfide exposure standards. To date, the exposure standards have been developed only for dimethyl disulphide.

\section{References}

1. Rahimov TH. Sovershenstvovanie processa pervichnoj pererabotk nefti i gazovogo kondensata s polucheniem serosoderzhashhih soedinenij i uglevodorodov [dissertacija]. Ufa, 2020. Russian.

2. Meshhakova NM, Benemanskij V. Ocenka biologicheskogo dejstvija dimetildisul'fida s uchetom specificheskih otdalennyh jeffektov. Bjulleten' VSNC SO RAMN. 2005; 2: 209-12. Russian.

3. Jurkevich ES, Prismotrov YuA. Nauchnoe obosnovanie orientirovochno bezopasnogo urovnja vozdejstvija dimetildisul'fida $\vee$ vozduhe rabochej zony. Zdorov'e i okruzhajushhaja sreda. 2009; 13: 51521. Russian.

4. Obzor rynka disul'fidnogo masla v Rossii. M.: Infomajn, 2012; 107 s. Russian.

5. Morgott D, Lewis C, Bootman J, Banton M. Disulfide oil hazard assessment using categorical analysis and a mode of action determination. Int J Toxicol. 2014; 33 (1): 181-98.

6. Munday R. Harmful and beneficial effects of organic monosulfides,

\section{Литература}

1. Рахимов Т. Х. Совершенствование процесса первичной переработки нефти и газового конденсата с получением серосодержащих соединений и углеводородов [диссертация]. Уфра, 2020

2. Мещакова Н. М., Бенеманский В. В. Оценка биологического действия диметилдисульфида с учетом специфических отдаленных эффектов. Бюллетень ВСНЦ СО РАМН. 2005; 2: 209-12

3. Юркевич Е. С., Присмотров Ю. А. Научное обоснование ориентировочно безопасного уровня воздействия диметилдисульфида в воздухе рабочей зоны. Здоровье и окружающая среда. 2009; 13: 515-21.

4. Обзор рынка дисульфидного масла в России. М.: Инфомайн, 2012; 107 c.

5. Morgott D, Lewis C, Bootman J, Banton M. Disulfide oil hazard assessment using categorical analysis and a mode of action determination. Int J Toxicol. 2014; 33 (1): 181-98.

6. Munday R. Harmful and beneficial effects of organic monosulfides, disulfides, and polysulfides in animals and humans. Chem Res Toxicol. 2012; 25 (1): 47-60.

7. Valavanidis A, Vlahogianni T, Dassenakis M, Scoullos M. Molecular biomarkers of oxidative stress in aquatic organisms in relation to toxic environmental pollutants. Ecotoxicol Environ Saf. 2006; 64 (2): 178-89. 
8. Дюсенгалиев К. И. Физико-химические характеристики субститутов дисульфидного масла углеводородного сырья. Нефтяное дело. 2016; 5: 125-39.

9. Методические указания для определения ориентировочных безопасных уровней воздействия (ОБУВ) в атмосферном воздухе населенных мест. М., 1982; 17 с.

10. Вредные вещества: классификация и общие требования безопасности. ГОСТ 12.1.007.-76. М., 1976; 6 с.

11. Классификация опасности химической продукции. Общие требования. ГОСТ 32419-2013. М.: Стандартинформ, 2014; 25 с. 